\title{
Spatial Variability of Saturated Hydraulic Conductivity and its Links with other Soil Properties at the Commune Scale
}

\author{
Boguslaw Usowicz ( $\nabla$ b.usowicz@ipan.lublin.pl ) \\ Institute of Agrophysics \\ Jerzy Lipiec \\ Institute of Agrophysics
}

\section{Research Article}

Keywords: saturated hydraulic conductivity, intrinsic and dynamic soil properties, commune-scale variability, geostatistics, kriging maps

Posted Date: January 5th, 2021

DOI: https://doi.org/10.21203/rs.3.rs-138269/v1

License: (c) (i) This work is licensed under a Creative Commons Attribution 4.0 International License.

Read Full License

Version of Record: A version of this preprint was published at Scientific Reports on April 15th, 2021. See the published version at https://doi.org/10.1038/s41598-021-86862-3. 
Spatial variability of saturated hydraulic conductivity and its links with other soil properties at the commune scale

Boguslaw Usowicz, Jerzy Lipiec

Institute of Agrophysics, Polish Academy of Sciences, Doswiadczalna 4, 20-290 Lublin, Poland (b.usowicz@ipan.lublin.pl)

\section{Abstract}

Saturated hydraulic conductivity (SHC) is a key property for evaluating soil water movement and quality. Most studies on spatial variability of SHC have been performed soil at a field or smaller scale. Therefore, the aim of this work was to assess (quantify) the spatial distribution of SHC at the commune scale and its relationship with other soil properties, including intrinsic sand, silt, and clay contents, relatively stable organic carbon, cation exchange capacity (CEC), dynamic water content (WC), total porosity (FI), and dry bulk density (BD) in the surface layer $(0-20 \mathrm{~cm})$. The spatial relationships were assessed using a semivariogram and a cross-semivariogram. The studied commune $\left(140 \mathrm{~km}^{2}\right)$ with predominantly permeable sandy soils with low fertility and productivity is located in the south-eastern part of Poland (Podlasie region). The mean sand and organic carbon contents are 74 and 0.86 and their ranges (in \%) are 45-95 and 0.002-3.75, respectively. The number of individual samples varied from 216-228 (for SHC, WC, BD, FI) to 691 for the other soil properties. The best fitting models were adjusted to the empirical semivariogram (exponential) and the crosssemivariogram (exponential, Gaussian, or linear) used to draw maps with kriging. The results showed that, among the soil properties studied, SHC was most variable (coefficient of variation $77.3 \%)$ and significantly $(\mathrm{p}<0.05)$ positively correlated with total porosity $(\mathrm{r}=$ $0.300)$ and negatively correlated with soil bulk density $(\mathrm{r}=-0.283)$. The mean SHC was $2.597 \mathrm{~m} \mathrm{day}^{-1}$ and ranged from 0.01 up to $11.54 \mathrm{~m} \mathrm{day}^{-1}$. The spatial autocorrelation (range) of SHC in the single (direct) semivariograms was $0.081^{\circ}(8.1 \mathrm{~km})$, while it favourably increased up to $0.149-0.81^{\circ}(14.9-81 \mathrm{~km})$ in the cross-semivariograms using the OC contents, textural fractions, and CEC as auxiliary variables. The generated spatial maps allowed outlining two sub-areas with predominantly high SHC above $3.0 \mathrm{~m} \mathrm{day}^{-1}$ in the northern sandier (sand content $>74 \%$ ) and less silty ( silt content <22\%) part and, with lower SHC in the southern part of the commune. Generally, the spatial distribution of the SHC values in the commune area depended on the share of individual intrinsic textural fractions. On the other 
hand, the ranges of the spatial relationship between SHC and the intrinsic and relatively stable soil properties were much larger (from $\sim 15$ to $81 \mathrm{~km}$ ) than between SHC and the dynamic soil properties $(0.3-0.9 \mathrm{~km})$. This knowledge is supportive for making decisions related to land management aimed at reduction of hydraulic conductivity and chemical leaching and improvement of soil water resources and crop productivity.

Keywords: saturated hydraulic conductivity, intrinsic and dynamic soil properties, communescale variability, geostatistics, kriging maps

\section{Highlights}

Greater spatial dependence was found between SHC and intrinsic than dynamic soil properties

Positional similarity between high sand content and high SHC was observed on maps Kriged maps can serve for planning soil management to control SHC in the commune

\section{Introduction}

Saturated hydraulic conductivity (SHC) determines the maximum capacity of soil to transmit water, pathways of water movement partitioning precipitation and irrigation water into surface runoff and retention in the soil ${ }^{1,2}$, and the soil water dynamics in the soil profile ${ }^{3}$. High SHC leads to rapid water infiltration and drainage $e^{4,5}$ and reduced time for attenuation of dissolved agrochemicals before entering ground waters ${ }^{6}$, whereas low SHC increases surface runoff and erosion ${ }^{7,8}$. Thereby, SHC helps farmers to apply an appropriate amount of irrigation water ${ }^{9}$. Furthermore, SHC affects soil aeration capacity ${ }^{10,11}$ influencing nutrient transformations and uptake by plants ${ }^{12,13}$. Due to the numerous contributions, SHC is often used as a measure of soil physical quality (e.g. ${ }^{12}$ ). Also, it is a key parameter in mathematical models for predicting soil hydraulic behaviour ${ }^{2}, 14 \cdot 15$.

The SHC value depends largely on the pore size distribution (PSD), especially on the

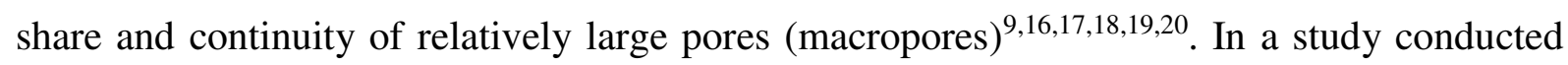
by $\mathrm{Kim}$ et al. $^{21}$, the area of the largest pores explained almost $80 \%$ of variability in soil saturated hydraulic conductivity. As shown by Centeno et al. ${ }^{22}$, macro-porosity can be used as a proxy to estimate the spatial variation of SHC.

Owing to the high sensitivity to pore size distribution influenced by soil texture and management practices, SHC displays relatively high spatial variability ${ }^{9,15,20,22,23}$. Therefore, knowledge of the spatial distribution of SHC is essential in selection of the most appropriate 
localised management practices and amendments to improve water use efficiency in agriculture and to minimise the use and leaching of chemicals ${ }^{24,25,26,27}$. The spatial distribution of soil properties, including saturated hydraulic conductivity, can be assessed by classical and spatial statistics. The classical statistics can adequately analyse variables that are independent of space $^{28}$. However, when the random variation occurs, geostatistical analysis including direct semivariograms and cross-semivariograms is appropriate ${ }^{29,30}$. Semivariograms define the dependence of the values of a given variable on the distance between sampling locations and, hence, the spatial structure of the variation. They aid in designing a sampling setup with an amount of samples required for satisfactory description of soil properties ${ }^{31,32}$. Once various variables are linked, their combined spatial designs can be evaluated by crosssemivariograms. Cross-semivariogram data and maps obtained using the cokriging technique allow distinguishing time-consuming and/or expensive variables from those that are more easily measured or available in soil databases. When SHC shows spatial random variation, the use of both classical statistics and geostatistical stochastic models is recommended ${ }^{30}$.

Numerous studies on the spatial variability of soil SHC have been performed to date at a short scale $(<25 \mathrm{~m})\left(\right.$ e.g. $\left.{ }^{33,34}\right)$ or a field scale ${ }^{35}$. However, the variability at a larger scale is poorly understood, as suitable spatial characterisation of highly heterogeneous SHC requires a large number of laborious, time-consuming, and expensive direct measurements ${ }^{9,36,37}$. To overcome these constraints, we have estimated the spatial distribution of SHC at the commune scale using a semivariogram and a cross-semivariogram and its relationship with soil properties that affect conductivity and can be more easily measured or obtained from existing soil databases.

\section{Materials and methods}

\subsection{Study area and sampling}

Trzebieszów commune with an area of about $140 \mathrm{~km}^{2}$ is situated in a flat area within Łuków Plain, Podlasie region, south-eastern Poland. The height differences in the shallow and often wet river (Krzna) valleys do not exceed $10 \mathrm{~m}$. The commune has mostly low productive Podzol soils ${ }^{38}$ derived from sandy and sandy loams of glacial origin. About $80 \%$ of the commune area is used in agriculture, with $62.3 \%$ and $18.2 \%$ of arable lands and grasslands, respectively. Forests cover only $13.5 \%$ of the commune area, mostly in the south-eastern and western parts. The climate is largely influenced by the western circulation and polar sea air (about $65 \%$ days a year). The average annual air temperature in the region is about $7.3^{\circ} \mathrm{C}$. July and January are the warmest and coldest months with respective mean temperatures of 
17.7 and $-3.6^{\circ} \mathrm{C}$. The annual amplitude of air temperature calculated from the monthly averages of January and July is $21.3^{\circ} \mathrm{C}$, and $23.4^{\circ} \mathrm{C}$ when calculated from the differences of the average temperature of the hottest and coldest month in individual years. The greatest amount of precipitation is recorded in June and July (more than $70 \mathrm{~mm}$ ) and the lowest values (less than $30 \mathrm{~mm}$ ) are noted in January, February, and March. This indicates significant predominance of summer rainfall $(212 \mathrm{~mm})$ over winter rainfall $(83 \mathrm{~mm})$. The sum of rainfall in the growing season (April - September), i.e. $350.9 \mathrm{~mm}$, constitutes $65.4 \%$ of the annual total. During the 50 years under consideration, it ranged from 224 to $530 \mathrm{~mm}$.

\subsection{Tested soil properties}

Soil samples were randomly collected from a 0-20 cm layer into cloth bags and $100 \mathrm{~cm}^{3}$ Kopecky cylinders immediately after harvesting cereals (August). The number of individual samples varied from 216-228 (for SHC, WC, BD, FI) to 691 for the other soil properties. Figure 1 shows the spatial distribution of the soil sampling points.

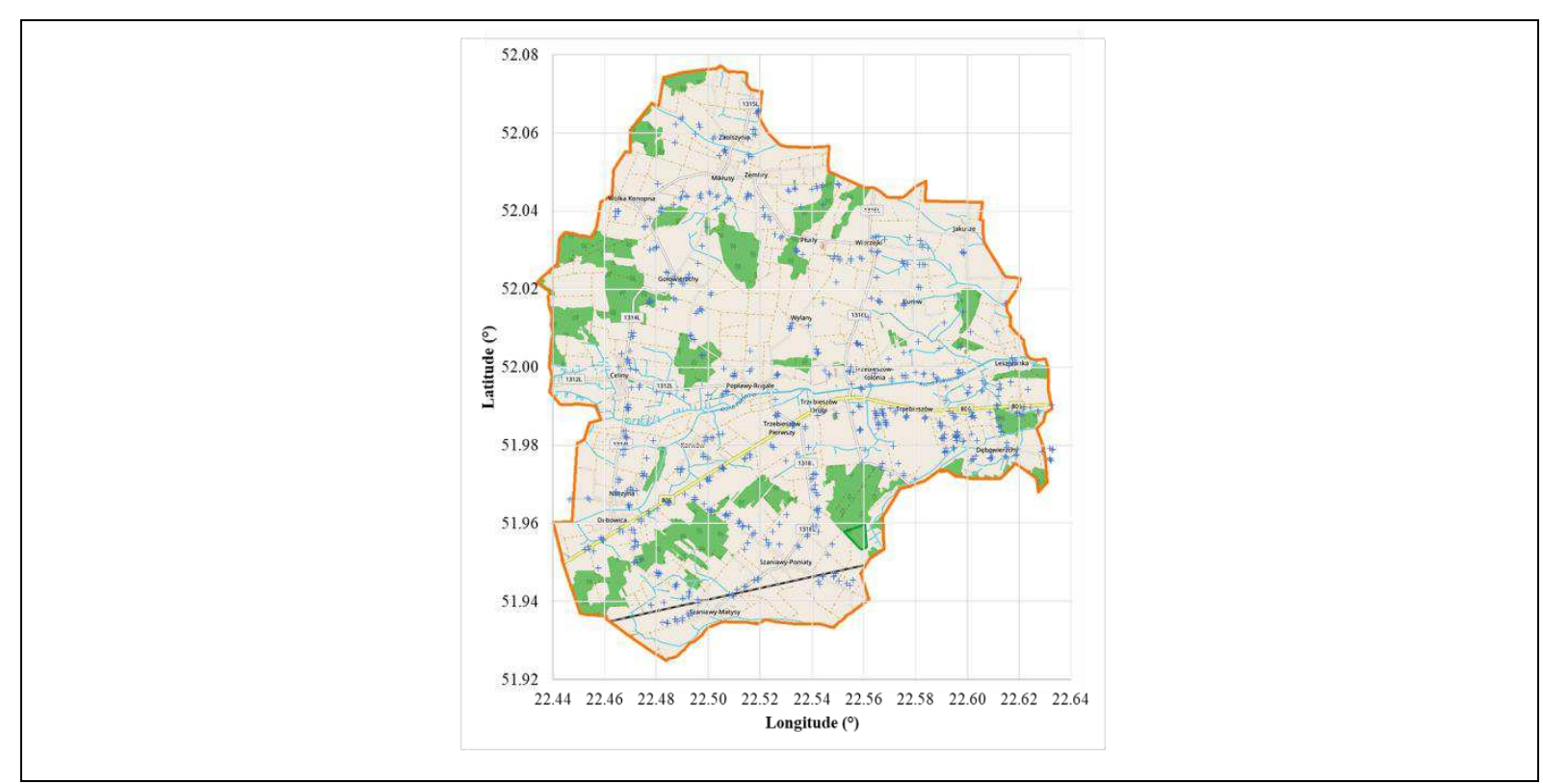

Fig. 1. Location of sampling points in Trzebieszów commune. Background maps from https://upload.wikimedia.org/wikipedia/commons/d/d4/Trzebiesz\%C3\%B3w_\%28gmina\%29 _location_map.png

Soil dry bulk density $\left(\mathrm{Mg} \mathrm{m}^{-3}\right)$ was determined with the gravimetric method from the ratio of the mass of soil dried at $105^{\circ} \mathrm{C}$ to the soil volume of $100 \mathrm{~cm}^{3}{ }^{39}$. The gravimetric water content $\left(\mathrm{WC}_{\text {grav }}\right)$ was determined from the ratio between water mass and mass of the soil after drying using the same cylinders as for determination of dry bulk density. Soil water content was also measured using a TDR meter $\left(\mathrm{WC}_{\mathrm{TDR}}\right)$ close to the sampling sites. Saturated 
hydraulic conductivity was measured with the constant head method in soil samples with a volume of $100 \mathrm{~cm}^{3}$ in a laboratory permeameter (Eijkelkamp Agrisearch Equipments, The Netherlands $)^{40}$. Particle size distribution was analysed using the sieving and hydrometer method $^{41}$. Soil organic matter was determined based on wet oxidation with $\mathrm{K}_{2} \mathrm{Cr}_{2} \mathrm{O}_{7}$ according to Tiurin's procedure ${ }^{41}$. The soil $\mathrm{pH}\left(\right.$ in $\mathrm{H}_{2} \mathrm{O}$ ) was determined potentiometrically using a composite electrode. Particle density $\left(\mathrm{Mg} \mathrm{m}^{-3}\right)$ was determined with the pycnometric method $^{42}$. The total porosity $\left(\mathrm{m}^{3} \mathrm{~m}^{-3}\right)$ was calculated as a ratio of $1-$ bulk density/particle density ${ }^{43}$.

\subsection{Data analysis}

\subsubsection{Classical statistics}

Basic statistics with the mean, standard deviation, coefficient of variation, minimum, maximum, skewness, and kurtosis were calculated for each soil property. Both kurtosis and skewness values of 0 indicate in general symmetrical distribution with a similar right tail (positive) and left tail (negative) of the distribution curve. When one tail is longer than the other, the distribution is asymmetric. As shown by Dahiya et al. ${ }^{44}$, the variability of the soil properties was categorised as low (0-15\%), medium (15-75\%), and high (>75\%). Pearson correlation coefficients between the soil variables were determined. The results were analysed using STATISTICA 12 PL (StatSoft 2019) and GS+105.

\subsubsection{Geostatistical methods}

\section{Semivariograms and cross-semivariograms}

It is assumed that values of soil properties or physical quantities measured in a given point are dependent (similar, correlated) on other points. In this approach, similarity is described by half of the value expected from the difference between the value of $Z(x)$ of the variable at point $x$ and the value of $Z(x+h)$ at a point distant by vector $h$. A variable whose values correspond to values $Z(x)$ is "regionalised". This variable has a random aspect, which takes into account local anomalies, including a structural aspect reflecting the multiscale trend of the phenomenon (trend). The analysis of this variable consists in identifying the structure of the variation. Three phases of the analysis can be distinguished: preliminary examination of collected data and evaluation of basic statistics, calculation of the empirical variant of the considered regionalised variable, and adjustment of the mathematical model to the course of the empirical variant. The knowledge of the first two statistical moments of random functions is required: the first (expected value) and the second (variance) moment. It is also required 
that the examined process is stationary, i.e. it does not change its properties when changing the beginning of the time scale or spatial scale. In the case of fulfilment of the stationary process, the random function $Z(x)$ is defined as the second order stationary and then the expected value exists and does not depend on the position, and the experimental semivariogram $\chi(h)$ (for a single variable $z_{1}$ ) or the cross-semivariogram $\gamma_{12}(h)$ (for two variables $z_{1}$ and $z_{2}$ ) for distance $h$ are calculated from the following equations ${ }^{45}$ :

$$
\begin{gathered}
\gamma(h)=\frac{1}{2 N(h)} \sum_{i=1}^{N(h)}\left[z_{1}\left(x_{i}\right)-z_{1}\left(x_{i}+h\right)\right]^{2} \\
\gamma_{12}(h)=\frac{1}{2 N(h)} \sum_{i=1}^{N(h)}\left[z_{1}\left(x_{i}\right)-z_{1}\left(x_{i}+h\right)\right] \cdot\left[z_{2}\left(x_{i}\right)-z_{2}\left(x_{i}+h\right)\right]
\end{gathered}
$$

where $N(h)$ is the number of pairs of points with values of $\left[z_{1}\left(x_{i}\right), z_{1}\left(x_{i}+h\right)\right],\left[z_{2}\left(x_{i}\right), z_{2}\left(x_{i}+h\right)\right]$, distant by $h$.

Three characteristic parameters for the semivariograms and cross-semivariograms are distinguished: nugget effect, threshold, and range. When the value of the semivariograms increases not from zero but from a certain value, this value is called the nugget effect. It expresses the variability of the examined physical quantity at a scale smaller than the sampling interval and/or accuracy of measurement. A value at which no further increase in the semivariograms is observed (approximately equal to the sample variance) is called a sill, while the distance from zero to the point where the semi- or cross-semivariogram reaches $95 \%$ of the sill value is called a range. The latter expresses the greatest distance at which the sampled values are auto- or cross-correlated.

For semi- and cross-semivariograms determined empirically, the following mathematical models were fitted using the least squares method $^{45}$ :

- The linear isotropic model describes a straight line variogram. There is no sill in this model; the range $A_{0}$ is defined arbitrarily to be the distance interval for the last lag class in the variogram. The formula used is:

$$
\gamma(h)=C_{0}+\left[h\left(C / A_{0}\right)\right]
$$

- The exponential isotropic model. The formula used for this model is: 
$\gamma(h)=C_{0}+C \cdot\left[1-e^{-\frac{|h|}{A_{0}}}\right] \quad|h|>0$

- The Gaussian isotropic model. The formula used for this model is:

$\gamma(h)=C_{0}+C \cdot\left[1-e^{-\frac{|h|^{2}}{A_{0}^{2}}}\right] \quad|h|>0$

where: $\chi(h)$ semivariance for internal distance class $h, h$ - lag interval, $C_{0}$ - nugget variance $\geq$ $0, C$ - structural variance $\geq C_{0}, A_{0}$ - range parameter. In the case of the linear model, there is no effective range $A-$ it is set initially to the separation distance $(h)$ for the last lag class graphed in the variogram. In the case of the spherical model, the effective range $A=A_{0}$. In the case of the exponential model, the effective range $A=3 A_{0}$, which is the distance at which the sill $\left(C+C_{0}\right)$ is within $5 \%$ of the asymptote. In the case of the Gaussian model, the effective range $A=3{ }^{0.5} A_{0}$, which is the distance at which the sill $\left(C+C_{0}\right)$ is within $5 \%$ of the asymptote.

The fractal dimension $D$ was determined based on the $\log -\log$ semivariogram plots using the formula ${ }^{46}$ :

$D=2-\frac{H}{2}$

where: $H$ is the slope of the semivariogram line plotted in the logarithmic system of coordinates.

\section{Kriging}

The estimation of values in unmeasured places was conducted using the kriging estimation method. This method gives the best unbiased estimate of the point or block values of the variable under study with minimal variance during the estimation process. The values of the kriging variance depend on the position of the samples in relation to the estimated location, the weights assigned to the samples, and the parameters of the semivariogram model and is described by a linear equation expressed by the formula ${ }^{45}$ :

$$
z^{\bullet}\left(x_{o}\right)=\sum_{i=1}^{N} \lambda_{i} z\left(x_{i}\right)
$$

where $N$ is the number of measurements, $z\left(x_{i}\right)$ is the measured value at the point $x_{i}, z^{*}\left(x_{o}\right)$ is the value estimated at the estimation point $x_{o}$, and $\lambda_{i}$ are the weights. The weights are 
determined from the system of equations taking into account the condition of non-loadability and efficiency of the estimator, i.e. when the expected value of the difference between the measured and estimated values is zero and the variance of the differences is minimal ${ }^{45}$ :

$$
\left\{\begin{array}{l}
\sum_{j=1}^{N} \lambda_{j} \gamma\left(x_{i}, x_{j}\right)+\mu=\gamma\left(x_{i}, x_{o}\right) \quad i=1 \ldots N \\
\sum_{i=1}^{N} \lambda_{i}=1
\end{array}\right.
$$

Solving the above system of equations, we determined the weights of kriging $-\lambda_{i}$. These weights allow also determination of the estimated value $z^{*}$ and its variance from the formula: $\sigma_{k}^{2}\left(x_{o}\right)=\mu+\sum_{i=1}^{N} \lambda_{i} \gamma\left(x_{i}, x_{o}\right)$

Regular ordinary kriging (OK) was used for the estimation, as it gave a good match between the measured and the estimated value. The inverse distance weighting interpolation (IDW) was a worse interpolator, while the regular cokriging (OCK) did not appreciably improve the estimation compared to OK.

\section{Results}

\subsection{Classical statistics}

The statistical parameters of the examined soil characteristics in the studied commune are summarised in Table 1. The mean saturated hydraulic conductivity of the soils was $2.597 \mathrm{~m}$ day $^{-1}$ and ranged from 0.01 up to $11.54 \mathrm{~m} \mathrm{day}^{-1}$. The average sand, silt, and clay contents and their ranges (in \%) were 74, 24.5, 1.5 and 45-95, 4-54, 0-6, respectively. The silt content was always lower than that of sand and higher than that of clay at all sampling points. The content of organic carbon in the commune soils was low, i.e. on average $0.86 \%$ with the minimum and maximum values 0.002 and $3.75 \%$ at single measurement points. The reaction of the soils in general was either acidic or neutral with the mean, minimum, and maximum $\mathrm{pH}\left(\mathrm{in}_{2} \mathrm{O}\right)$ values of 5.3, 4.0, and 7.2, respectively. The mean cation exchange capacity (CEC) was 9.67 cmol kg$~^{-1}$ and ranged from 3.05 to $21.2 \mathrm{cmol} \mathrm{kg}^{-1}$. The average soil moisture measured with the TDR meter and gravimetrically was similar and amounted to approx. $0.07\left(\mathrm{~m}^{3} \mathrm{~m}^{-3}\right)$, whereas the respective ranges were $0.001-0.232 \mathrm{~m}^{3} \mathrm{~m}^{-3}$ and $0.009-0.287 \mathrm{~m}^{3} \mathrm{~m}^{-3}$. The mean, minimum, and maximum values of bulk density and total porosity were $1.414,0.998,1.681$ 
$\mathrm{Mg} \mathrm{m}^{-3}$ and $0.424,0.308,0.524 \mathrm{~m}^{3} \mathrm{~m}^{-3}$, respectively. As in the study conducted by Dahiya et al. ${ }^{44}$ (1984), the variability was low for soil bulk density, total porosity, sand content, and $\mathrm{pH}$ in $\mathrm{H}_{2} \mathrm{O}(\mathrm{CV} 8.8-13.8 \%)$, medium for CEC, silt content, $\mathrm{OC}, \mathrm{WC}_{\mathrm{TDR}}$, and $\mathrm{WC}_{\text {grav }}(32.1-$ $67.4 \%$ ), and high for saturated hydraulic conductivity (77.3\%). Skewness, which characterises the degree of asymmetry of the distribution around the mean, was moderate $(<1)$ for most variables and slightly more positive $(<2)$ for soil moisture, clay content, and saturated hydraulic conductivity. Silt content and bulk density showed a slight negative asymmetry of $(<-1)$. Kurtosis, which characterises the relative slenderness or flatness of the distribution compared to the normal distribution (zero), was close to zero for most variables. We noted relatively little flattening for sand, silt, and $\mathrm{pH}$ (in $\left.\mathrm{H}_{2} \mathrm{O}\right)(<0$ or from -0.130 to -0.158$)$, slight slenderness for bulk density and porosity $(<0.053$ or from 0.030 to -0.030$)$, and somewhat higher value for CEC ( $<1$ or 0.956). Soil moisture, the OC and clay contents, and saturated hydraulic conductivity showed much greater slenderness of distribution (2.218-4.826). The differences between the mean values and the medians for individual variables as well as the values of asymmetry and kurtosis indicate that the studied variables can be described with a normal distribution with fairly good accuracy. Those with greater asymmetry were squareroot or natural-logarithm transformed, thus their data distributions were close to the normal distribution (Table 1).

Table 1. Basic statistics for soil properties at a depth of 0-20 cm in experimental Trzebieszów commune

\begin{tabular}{|c|c|c|c|c|c|c|c|c|}
\hline Properties & $\mathrm{N}$ & Mean & Minimum & Maximum & SD & $\mathrm{CV}(\%)$ & Skewness & Kurtosis \\
\hline $\mathrm{K}$ & 216 & 2.597 & 0.010 & 11.54 & 2.009 & 77.3 & 1.951 & 4.826 \\
\hline sand & 691 & 74.0 & 45.0 & 95.0 & 9.3 & 12.6 & 0.094 & -0.130 \\
\hline silt & 691 & 24.5 & 4.0 & 54.0 & 9.2 & 37.5 & -0.074 & -0.142 \\
\hline clay & 691 & 1.52 & 0.0 & 6.0 & 0.905 & 59.4 & 1.537 & 4.183 \\
\hline $\mathrm{pH}_{\mathrm{H} 2 \mathrm{O}}$ & 691 & 5.27 & 4.04 & 7.2 & 0.728 & 13.8 & 0.680 & -0.158 \\
\hline $\mathrm{OC}$ & 691 & 0.862 & 0.002 & 3.8 & 0.427 & 49.5 & 0.904 & 3.684 \\
\hline CEC & 691 & 9.675 & 3.050 & 21.2 & 3.109 & 32.1 & 0.654 & 0.956 \\
\hline $\mathrm{WC}_{\text {grav. }}$ & 228 & 0.067 & 0.009 & 0.287 & 0.045 & 67.4 & 1.626 & 3.586 \\
\hline $\mathrm{WC}_{\mathrm{TDR}}$ & 228 & 0.071 & 0.001 & 0.232 & 0.038 & 53.7 & 1.330 & 2.218 \\
\hline BD & 228 & 1.413 & 0.998 & 1.681 & 0.125 & 8.9 & -0.540 & 0.030 \\
\hline \multirow[t]{2}{*}{ FI } & 228 & 0.425 & 0.308 & 0.525 & 0.038 & 8.9 & 0.000 & -0.030 \\
\hline & \multicolumn{8}{|c|}{ Transformed data with a square root (sqr) and natural logarithm (ln) } \\
\hline $\operatorname{sqr}(\mathrm{K}$ & 216 & 1.507 & & & 0.573 & 38.0 & 0640 & 1.080 \\
\hline $\mathrm{sqr}(\mathrm{c}$ & 6 & 1.1 & & & 0.403 & 34.6 & -0 & 2.570 \\
\hline $\ln \left(\mathrm{pHH}_{2} \mathrm{O}\right)$ & 691 & 1.653 & 0 & 1.980 & 0.134 & 8.1 & 0.410 & -0.510 \\
\hline $\operatorname{sqr}(O$ & 691 & 0.8 & & 40 & 0.248 & 27.7 & -0.520 & 1.490 \\
\hline $\operatorname{sqr}(\mathrm{C}$ & 691 & 3.070 & & & 0.499 & 16.3 & 0.100 & 0.300 \\
\hline $\ln \left(\mathrm{WC}_{\text {grav }}\right)$ & 228 & -2.914 & -4.710 & -1.250 & 0.667 & 22.9 & -0.200 & -0.250 \\
\hline $\operatorname{sqr}\left(W_{\mathrm{TDR}}\right)$ & 228 & 0.258 & 0.032 & 0.482 & 0.068 & 26.5 & 0.450 & 0.680 \\
\hline
\end{tabular}


$\mathrm{N}$ - number of samples, SD - standard deviation, CV - coefficient of variation, $\mathrm{K}$ - saturated hydraulic conductivity $\left(\mathrm{m} \mathrm{day}^{-1}\right)$, sand $-(2-0.05 \mathrm{~mm})$, silt $-(0.05-0.002 \mathrm{~mm})$, clay $<0.002 \mathrm{~mm}, \mathrm{pH}_{\mathrm{H} 2 \mathrm{O}}-$ acidity $(-), \mathrm{OC}-$ organic carbon (\%), CEC - cation exchange capacity $\left(\mathrm{cmol} \mathrm{kg}{ }^{-1}\right), \mathrm{WC}_{\text {grav }}-$ gravimetric water content $\left(\mathrm{m}^{3} \mathrm{~m}^{-3}\right)$, $\mathrm{WC}_{\mathrm{TDR}}$ - water content in time-domain reflectometry $\left(\mathrm{m}^{3} \mathrm{~m}^{-3}\right)$, BD - bulk density $\left(\mathrm{Mg} \mathrm{m}^{-3}\right), \mathrm{FI}-$ porosity $\left(\mathrm{m}^{3}\right.$ $\left.\mathrm{m}^{-3}\right)$.

\subsection{Correlation analysis}

The linear correlation coefficients ( $r$ ) between the considered soil properties are summarised in Table 2 (the values marked in bold are statistically significant at $\mathrm{p}<0.05$ ). The saturated water conductivity of the soil was significantly-positively correlated with the porosity $(0.300)$ and negatively with the soil density $(-0.283)$. Other significant correlation coefficients were found between sand and silt contents $(-0.996)$ and sand and clay $(-0.182)$. There was no significant correlation between the contents of silt and clay. Soil $\mathrm{pH}\left(\right.$ in $\mathrm{H}_{2} \mathrm{O}$ ) and $\mathrm{OC}$ were negatively correlated $(\mathrm{p}<0.05)$ with the sand content $(-0.177,-0.175$, respectively) and positively with the silt content $(0.178,0.168$, respectively). CEC was negatively and significantly correlated $(\mathrm{p}<0.05)$ with the sand content $(-0.519)$ and positively correlated with silt, clay, $\mathrm{pH}$, and OC (0.160-0.607).

The significant correlation between the gravimetric vs. TDR soil moistures $(0.876)$ indicates suitability of the TDR measurement system, which is widely used as a benchmark for validation of satellite soil moisture products (e.g. $\left.{ }^{47}\right)$. Soil moisture did not significantly correlate with other soil properties. Soil porosity correlated negatively ( $p<0.05$ ) with the bulk density and sand and silt contents $(-0.737,-0.142)$ and positively with the sand content (0.145).

Table 2. Correlation coefficients (r) between soil variables in Trzebieszów commune

\begin{tabular}{|c|c|c|c|c|c|c|c|c|c|c|c|}
\hline & Marke & d correla & ion coeff & icients a & signific & ant at $\mathrm{p}$ & $0.05, \mathrm{~N}=$ & $=216$ & & & \\
\hline Properties & sand & silt & clay & $\mathrm{pH}_{\mathrm{H} 2 \mathrm{O}}$ & $\mathrm{OC}$ & $\mathrm{CEC}$ & $\mathrm{WC}_{\text {grav }}$ & $\mathrm{WC}_{\mathrm{TDR}}$ & $\mathrm{BD}$ & FI & $\mathrm{K}$ \\
\hline sand & 1.000 & -0.996 & -0.181 & -0.177 & -0.175 & -0.519 & -0.060 & -0.068 & -0.084 & 0.145 & -0.034 \\
\hline silt & & 1.000 & 0.092 & 0.178 & 0.168 & 0.470 & 0.062 & 0.071 & 0.083 & -0.142 & 0.034 \\
\hline clay & & & 1.000 & 0.006 & 0.107 & 0.607 & -0.016 & -0.020 & 0.031 & -0.056 & 0.003 \\
\hline $\mathrm{pH}_{\mathrm{H} 2 \mathrm{O}}$ & & & & 1.000 & 0.019 & 0.160 & 0.029 & 0.070 & -0.007 & -0.068 & -0.060 \\
\hline $\mathrm{OC}$ & & & & & 1.000 & 0.521 & -0.039 & -0.016 & -0.078 & 0.007 & 0.062 \\
\hline CEC & & & & & & 1.000 & -0.013 & -0.005 & -0.006 & -0.079 & 0.034 \\
\hline $\mathrm{WC}_{\text {grav. }}$ & & & & & & & 1.000 & 0.876 & 0.116 & 0.028 & -0.004 \\
\hline $\mathrm{WC}_{\mathrm{TDR}}$ & & & & & & & & 1.000 & 0.192 & -0.059 & -0.026 \\
\hline $\mathrm{BD}$ & & & & & & & & & 1.000 & -0.735 & -0.283 \\
\hline FI & & & & & & & & & & 1.000 & 0.300 \\
\hline $\mathrm{K}$ & & & & & & & & & & & 1.000 \\
\hline
\end{tabular}


time-domain reflectometry $\left(\mathrm{m}^{3} \mathrm{~m}^{-3}\right), \mathrm{BD}-$ bulk density $\left(\mathrm{Mg} \mathrm{m}^{-3}\right), \mathrm{FI}-$ porosity $\left(\mathrm{m}^{3} \mathrm{~m}^{-3}\right), \mathrm{K}-$ saturated hydraulic conductivity $\left(\mathrm{m} \mathrm{day}^{-1}\right)$

\subsection{Geostatistical analysis}

The fitted semivariogram models for SHC and cross-semivariograms for pairs of crosscorrelated SHC and other soil properties are presented in Table 3. In general, there was a good agreement between the theoretical exponential models for all soil properties and the empirical semivariograms, as indicated by the high values of the determination coefficients $\left(\mathrm{R}^{2}\right.$ from 0.592 to 0.923 ) and the sum of squared residuals (RSS) from $<10^{-6}$ to 81.4 depending on soil properties. This agreement for the cross-semivariograms was fairly good in six cases $\left(\mathrm{R}^{2}>0.284\right)$, and poor in two $\left(\mathrm{R}^{2} \sim 0.02\right)$. The RSS values were small for most models $\left(5.94 \times 10^{-3}-7.62 \times 10^{-6}\right)$. In the cross-semivariograms analysis, five soil properties had exponential dependency, four - Gaussian, and one - linear. The presence of nugget effects indicates that the variability of the examined features is smaller than the adopted minimum distance between the measurement points. The sill values of the semivariance are comparable with the values of variance obtained in the classical way (Tables 1 and 3), which may indicate lack of clear trends in the data. The sill values of the semivariograms were a derivative of the content of individual textural fractions. The highest sill values were recorded for the sand and silt contents. However, they were lower for saturated hydraulic conductivity and substantially lower for the contents of clay, organic matter, moisture, and $\mathrm{pH}$, cation exchange capacity, bulk density, and total porosity. The range of spatial dependence displayed by the semivariograms was the smallest for $\mathrm{pH}\left(0.012^{\circ}\right)$, intermediate for $\mathrm{OC}, \mathrm{CEC}$, clay, sand, silt, $\mathrm{BD}, \mathrm{WC}_{\text {grav }}$, and $\mathrm{WC}_{\mathrm{TDR}}$ porosity $\left(0.018-0.057^{\circ}\right)$, and the largest for saturated hydraulic conductivity $\left(0.081^{\circ}\right)$. In the case of the cross-semivariograms for pairs of cross-correlated SHC with intrinsic and relatively stable properties (sand, silt, clay, OC, CEC, pH), the spatial ranges were much larger (from 0.095 to $0.81^{\circ}$ ) than with dynamic ones, such as gravimetric and TDR soil moistures, bulk density, and total porosity $\left(0.003-0.009^{\circ}\right)$. As shown by Cambardella et al. $^{48}$, the spatial dependences (nugget/sill) for all semivariograms were moderate $(0.25-0.75)$ and those for cross-semivariograms were in general strong $(<0.25)$. The distribution of the most widely studied soil properties showed anisotropy with orientation mostly from west to east. Only the clay content and CEC showed anisotropy from north to south. 
The estimation of the spatial distribution of the studied properties using the fractal theory showed that all soil properties were characterised by high values of the fractal dimensions $\mathrm{D}>1.9$, indicating a random distribution in the spatial organisation.

Table 3. Fitted semivariogram models (SV) for properties data used in the ordinary kriging interpolation method and cross-semivariogram models (CSV) between saturated hydraulic conductivity and other soil properties; $1^{\circ}$ corresponds to approx. $100 \mathrm{~km}$.

\begin{tabular}{|c|c|c|c|c|c|c|c|c|c|}
\hline \multirow[b]{2}{*}{ Properties } & \multicolumn{9}{|c|}{ Semivariogram models (SV) } \\
\hline & Model & $C_{0}$ & $C_{0}+C$ & $\mathrm{C}_{0} /\left(C_{0}+C\right)$ & $A\left({ }^{\circ}\right)$ & $\mathrm{R}^{2}$ & RSS & $A_{z}\left(^{\circ}\right)$ & D0 \\
\hline K & Exp. & 2.223 & 4.774 & 0.466 & 0.081 & 0.666 & $2.83 \mathrm{E}+00$ & 75 & 1.908 \\
\hline $\operatorname{sqr}(\mathrm{K})$ & Exp. & 0.187 & 0.374 & 0.499 & 0.063 & 0.592 & $1.26 \mathrm{E}-02$ & 75 & 1.945 \\
\hline sand & Exp. & 41.4 & 89.57 & 0.462 & 0.024 & 0.911 & $8.14 \mathrm{E}+01$ & 96 & 1.945 \\
\hline silt & Exp. & 41.6 & 87.39 & 0.476 & 0.024 & 0.903 & $8.03 \mathrm{E}+01$ & 96 & 1.948 \\
\hline sqr(clay) & Exp. & 0.082 & 0.1714 & 0.478 & 0.024 & 0.733 & $6.35 \mathrm{E}-04$ & 0 & 1.961 \\
\hline $\ln \left(\mathrm{pH}_{\mathrm{H} 2 \mathrm{O}}\right)$ & Exp. & 0.00563 & 0.01796 & 0.313 & 0.012 & 0.699 & $2.39 \mathrm{E}-06$ & 124 & 1.973 \\
\hline $\operatorname{sqr}(\mathrm{OC})$ & Exp. & 0.0311 & 0.0631 & 0.493 & 0.021 & 0.923 & $1.25 \mathrm{E}-05$ & 83 & 1.960 \\
\hline $\operatorname{sqr}(\mathrm{CEC})$ & Exp. & 0.1246 & 0.2532 & 0.492 & 0.018 & 0.904 & $2.32 \mathrm{E}-04$ & 0 & 1.968 \\
\hline $\ln \left(\mathrm{WC}_{\text {grav }}\right)$ & Exp. & 0.1727 & 0.4294 & 0.402 & 0.018 & 0.568 & $5.78 \mathrm{E}-03$ & 44 & 1.958 \\
\hline $\operatorname{sqr}\left(W_{\mathrm{TDR}}\right)$ & Exp. & 0.00244 & 0.00489 & 0.499 & 0.057 & 0.605 & $1.82 \mathrm{E}-06$ & 74 & 1.930 \\
\hline $\mathrm{BD}$ & Exp. & 0.00857 & 0.01724 & 0.497 & 0.045 & 0.609 & $1.40 \mathrm{E}-05$ & 117 & 1.948 \\
\hline \multirow[t]{2}{*}{ FI } & Exp. & 0.00080 & 0.00149 & 0.541 & 0.045 & 0.782 & $5.56 \mathrm{E}-06$ & 105 & 1.943 \\
\hline & \multicolumn{9}{|c|}{ Cross-semivariogram models (CSV) of sqr(K) and properties } \\
\hline Properties & Model & $C_{0}$ & $C_{0}+C$ & $\mathrm{C}_{0} /\left(C_{0}+C\right)$ & $A\left({ }^{\circ}\right)$ & $\mathrm{R}^{2}$ & RSS & & \\
\hline sand & Gau. & -0.165 & -0.837 & 0.197 & 0.156 & 0.478 & 0.346 & & \\
\hline silt & Gau. & 0.170 & 0.762 & 0.223 & 0.149 & 0.419 & 0.380 & & \\
\hline sqr(clay) & Gau. & 0.0014 & 0.0463 & 0.030 & 0.240 & 0.316 & $9.42 \mathrm{E}-04$ & & \\
\hline $\ln \left(\mathrm{pH}_{\mathrm{H} 2 \mathrm{O}}\right)$ & Lin. & -0.00066 & -0.00066 & 1.000 & 0.095 & 0.284 & $1.61 \mathrm{E}-04$ & & \\
\hline $\operatorname{sqr}(\mathrm{OC})$ & Exp. & 0.00004 & 0.03148 & 0.001 & 0.810 & 0.177 & $5.21 \mathrm{E}-04$ & & \\
\hline sqr(CEC) & Gau. & 0.0014 & 0.0863 & 0.016 & 0.222 & 0.394 & $2.96 \mathrm{E}-03$ & & \\
\hline $\ln \left(\mathrm{WC}_{\text {grav }}\right)$ & Exp. & -0.0007 & -0.0235 & 0.030 & 0.006 & 0.013 & $5.94 \mathrm{E}-03$ & & \\
\hline $\operatorname{sqr}\left(\mathrm{WC}_{\mathrm{TDR}}\right)$ & Exp. & -0.00104 & -0.00286 & 0.364 & 0.009 & 0.020 & $6.34 \mathrm{E}-05$ & & \\
\hline $\mathrm{BD}$ & Exp. & -0.00001 & -0.02102 & 0.000 & 0.006 & 0.295 & $3.25 \mathrm{E}-05$ & & \\
\hline FI & Exp. & 0.00025 & 0.00604 & 0.041 & 0.003 & 0.237 & $7.62 \mathrm{E}-06$ & & \\
\hline
\end{tabular}

Exp. - exponential model, Lin. -linear model, Gau. -Gaussian model, $C_{0}-$ nugget variance, $\mathrm{C}_{0}+C-$ sill, $A-$ effective range $\left({ }^{\circ}\right)\left(1^{\circ}=\right.$ approx. $\left.100 \mathrm{~km}\right), \mathrm{R}^{2}$ - coefficient of determination, RSS -root sum square, $A_{z}-$ anisotropy $\left({ }^{\circ}\right.$ - slope angle), D0 - fractal dimension

\subsection{Kriging maps}

Based on the obtained models, semivariogram parameters, and measured data, commune scale maps of the soil properties were generated and the estimation errors were calculated (Fig. 2) using ordinary kriging. The estimation errors were $1-2 \%$ in the vicinity of the measurement points and up to approx. $10 \%$ at the edges of the estimated areas (measurement grids). 
In the northern part of the commune, the large island (area) between approximately $52.01^{\circ}$ and $52.04^{\circ}$ with high saturated hydraulic conductivities from 3.1 to $4.6 \mathrm{~m} \mathrm{day}^{-1}$ (Fig. 2) corresponds with the highest sand contents $(>74 \%)$ and the lowest contents of silt $(<22 \%)$. In the southern part of the commune below $52^{\circ}$, the lower saturated conductivities correspond with the lower sand content $(<74 \%)$, greater silt content $>24 \%$, and similar clay content $(<2.8 \%)$.

In general, latitudinal distribution can be observed for the sand and silt contents. Clay, $\mathrm{CEC}$, and $\mathrm{BD}$ are distributed in a small island and $\mathrm{OC}, \mathrm{pH}$, and gravimetric and TDR soil moistures - in larger islands. Cation exchange capacity (CEC) showed a relatively uniform distribution throughout the commune in small islands of higher or lower values. Organic carbon content (OC) had mostly an island distribution system with a slightly marked meridional distribution. It can be observed that both gravimetric and TDR soil moistures were more similar to that of the organic carbon content than other soil properties. The gravimetric vs. TDR soil moisture distribution was more variable, which implies greater sensitivity. The highest $\mathrm{BD}$ values correspond with the highest sand content and the lowest contents of clay and OC.

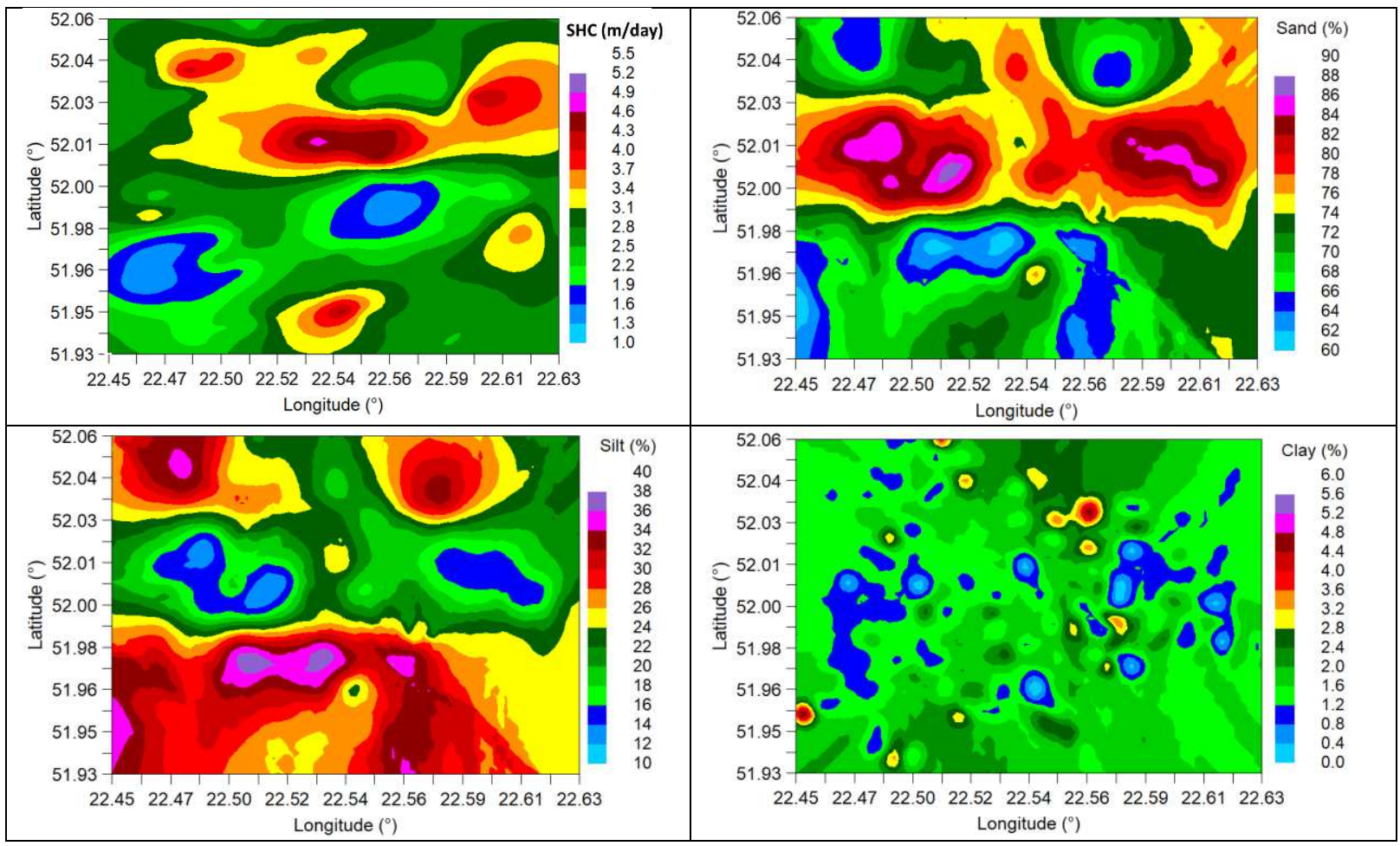




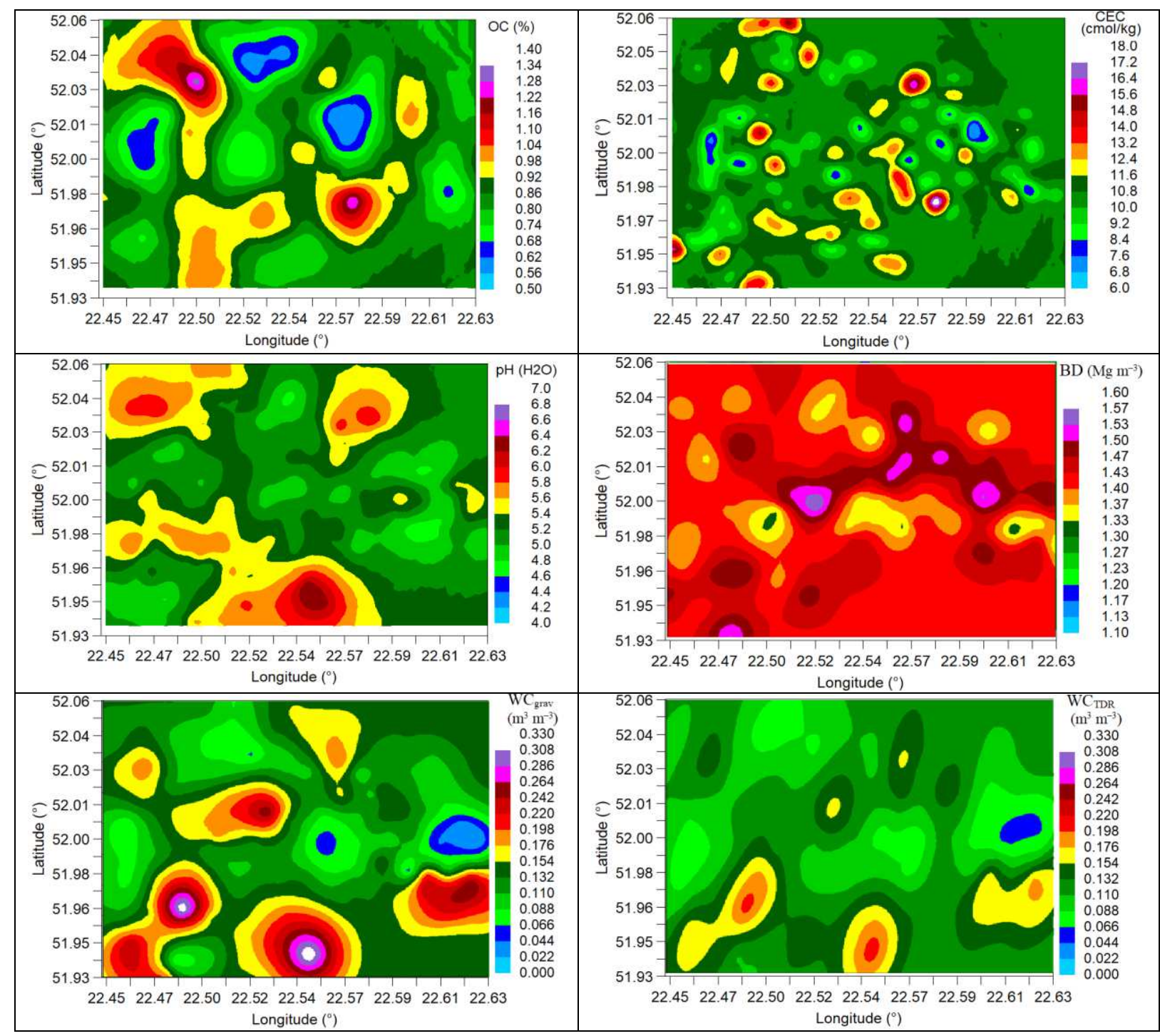

Fig. 2. Maps of saturated hydraulic conductivity (SHC), sand, silt, and clay contents, soil organic carbon (OC), cation exchange capacity (CEC), $\mathrm{pH}$, bulk density (BD), gravimetric water content $\left(\mathrm{WC}_{\text {grav }}\right)$ and $\mathrm{TDR}$ water content $\left(\mathrm{WC}_{\mathrm{TDR}}\right)$ in Trzebieszów commune

\section{Discussion}

\subsection{Geostatistical analysis}

SHC exhibited the strongest spatial heterogeneity (coefficient of variation $77.3 \%$ ) of all the soil studied properties. This can be largely influenced by various management practices, including crop rotation, tillage, liming, or history of land use and other treatments used at the commune scale. These management effects may be associated with changes in total porosity, which was significantly positively correlated with SHC ( $<$ <.05) (Table 2). Particularly important are large and connected (elongated) biological and inter-aggregate pores ${ }^{9,16,17}$. The spatially heterogeneous effect of the various management practices applied at the commune 
scale on SHC can mask the impact of intrinsic soil texture, as indicated by the poor and nonsignificant overall correlations between SHC and the contents of all textural fractions (Table 2). Probably, there was no significant effect of terrain attributes associated with the landscape level and pedogenetic processes on SHC, as the flat commune area within Łuków Plain is covered mainly by Podzol soils ${ }^{49,50}$.

The model parameters describing the spatial relationships of SHC with intrinsic and dynamic soil properties were better for the cross-semivariograms with auxiliary soil properties than for the direct semivariograms, as shown by the appreciably smaller nugget values $\left(C_{0}\right)$, the greater ranges $(A)$, and the stronger degree of spatial dependencies (nugget/sill) in the former. These differences were most pronounced when intrinsic (stable) and relatively stable soil properties, including the contents of textural fractions, OC, and CEC, were used as auxiliary variables $\left(C_{0}-0.165\right.$ to 0.170 vs. 2.23$), A 0.156^{\circ}(15.6 \mathrm{~km})$ to $0.810^{\circ}(81 \mathrm{~km})$ vs. $0.081^{\circ}(8.1 \mathrm{~km})$, nugget/sill 0.001 to 0.223 vs. 0.466$)$. This indicates that the intrinsic and relatively stable soil properties were spatially correlated with SHC although there was no significant linear correlation of each intrinsic or relatively stable soil property vs. SHC (Table 2 ). The smaller nugget values $\left(C_{0}\right)$ in the cross-semivariograms compared to the direct semivariograms imply smoother spatial continuity and stronger dependency between neighbouring sampling points $\mathrm{s}^{31,51,52}$. It is worth noting that the suitability of soil texture data used as auxiliary variables for improvement of the prediction of the spatial SHC distribution can be enhanced by their worldwide availability in soil geographic databases (e.g. ${ }^{53}$ ). It should be underlined that the range values of the cross-semivariograms (in the case of all pairs) exceeded the length and width of the commune $(\sim 13 \times 16 \mathrm{~km})$.

\subsection{Kriging maps}

The kriged maps generated in this study allowed outlining two sub-areas with predominantly saturated hydraulic conductivity (SHCs) $>3.0 \mathrm{~m} \mathrm{day}^{-1}$ in the northern part (latitude 52.0152.06) and $<3.0 \mathrm{~m} \mathrm{day}^{-1}$ in the southern part (52.00-51.93) of the commune. As reported by Stryjewski ${ }^{54}$, the SHC values in the northern part can be classified as high and very high and those in the southern part as fairly high and low. The comparison of the maps in Figure 2 shows positional similarity between the sub-area with the higher SHC value and those with the large sand content $(>74 \%)$ and the low silt content $(<22 \%)$. This similarity can be attributed to the effect of the sand fraction on the abundance of relatively large and connected pores that mostly contribute to high SHC (e.g. ${ }^{55}$ ). This effect can be illustrated by results from a study conducted by Lim et al. ${ }^{56}$, where SHC of $5.98 \mathrm{~m}_{\text {day }}{ }^{-1}$ of coarse sand decreased by 57 , 
88 , and $96 \%$ with the successively decreasing sand content in fine sand, loam, and clay textured soils. Our previous studies in the same commune area along with visual observations showed that limited crop growth and yields were spatially related to higher sand content ${ }^{50,57}$. This crop response in sandier and more permeable zones can be caused by excessive drainage of rainwater resulting in insufficient plant-available water for unsaturated conditions. Furthermore, the drainage contributes to chemical leaching, thereby limiting the availability of nutrients for plants. This explanation can be supported by the significant negative correlation between the sand content and cation exchange capacity (Table 2). This implies that high SHC can be an indicator of a low-yielding zone in the studied commune area with predominance of coarse-textured soils. This is in contrast to fine-textured soils where low SHC values are indicative of low-yielding zones. For example, in a study conducted by Keller et $\mathrm{al}^{3}$ on loam and clay soils with SHC varying from 0.6 to $25.2 \mathrm{~m} \mathrm{day}^{-1}$, lower saturated hydraulic conductivity was recorded in low-yielding zones than in high- and medium-yielding zones due to the more blocky soil structure in the former. The low yields in fine-textured soils with low saturated hydraulic conductivity often results from water ponding and limited oxygen concentrations for root and shoot growth, especially in wet years ${ }^{13}$. This indicates that the effect of spatial distribution of SHC on the spatial distribution of soil productivity and other soil functions depends on soil texture and weather conditions during the growing season. Therefore, different threshold SHC values with respect to productivity and other soil functions should be considered in the case of coarse- and fine-textured soils.

The kriged map of SHC can be useful for the commune authorities and agronomy advisers for spatial planning of management practices aimed at reduction of particularly high soil SHC. In coarse-textured soils, it can be reduced by addition of exogenous organic

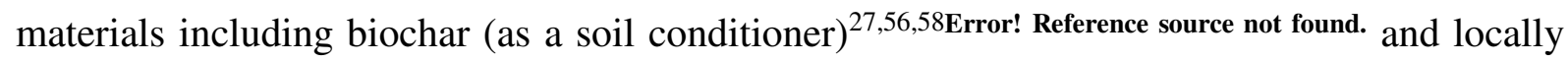
available recycled composted chicken manure or spent mushroom substrate after mushroom harvesting ${ }^{59,60}$. Such organic materials are currently applied in the studied commune area in research and by some farmers on agriculturally used sandy soils.

Another important agricultural management practice influencing SHC is crop rotation, including green manure cover crops or intercropping systems ${ }^{61,62}$. This practice is subsidised in several countries, including Poland, to increase soil organic carbon content ${ }^{63}$, improve soil structure $^{64}$, protect the soil surface from raindrop impact ${ }^{65}$, enhance fixation of atmospheric nitrogen in the case of legumes ${ }^{66}$, and improve agricultural productivity ${ }^{62}$. Over a longer time span, conversion of arable land into grassland that can serve as carbon and water storage may be an efficient option (e.g. $\left.{ }^{67}\right)$. 
Also re-compaction of loose soil by traffic leads to reduced SHC due to a decrease and increase in the large and small pore volumes, respectively ${ }^{68}$. However, this practice needs to be applied with caution to avoid excessive soil compaction and its harmful effect on root growth and crop yield ${ }^{13,69}$. Saturated hydraulic conductivity values $\leq 0.1 \mathrm{~m} \mathrm{day}^{-1}$ are used as an indicator of poor soil structure ${ }^{70}$ and more recently as threshold values of excessive soil compaction induced by vehicular traffic ${ }^{71}$. The SHC values in the commune area were in general above the thresholds, which may be in part related to the presence of predominantly small farms where relatively light agricultural vehicles and implements are used.

\section{Summary and conclusions}

The saturated hydraulic conductivity (SHC) of the soils in the studied commune $\left(140 \mathrm{~km}^{2}\right)$ varied from 0.01 to $11.54 \mathrm{~m} \mathrm{day}^{-1}$ and exhibited high spatial variability (CV 77.3\%). This variability was higher than that of the contents of textural fractions and organic carbon, cation exchange capacity, soil water content, bulk density, and total porosity (CV $8.9-67.4 \%$ ) (67.4\% for grav. soil moisture and $53.7 \%$ for TDR soil moisture). SHC was significantly ( $\mathrm{p}$ $<0.05)$ positively correlated with the total porosity $(\mathrm{r}=0.300)$ and negatively correlated with the soil bulk density $(\mathrm{r}=-0.283$ ). The spatial prediction (autocorrelation) of the soil properties using single (direct) semivariograms varied from $0.012^{\circ}(1.2 \mathrm{~km})$ for $\mathrm{pH}$ to $0.081^{\circ}$ $(8.1 \mathrm{~km})$ for SHC. Areas with larger SHC values are mainly determined by the proportion of sand and silt and those with smaller SHC - by the proportion of clay. The range of spatial dependence in the cross-semivariograms between SHC and sand and silt contents used as secondary variables was smaller (about $15 \mathrm{~km}$ ) than that of cation exchange capacity, clay content, and organic carbon content used as secondary variables (about 22 to $81 \mathrm{~km}$ ). However, the range of the spatial dependence prediction in the cross-semivariograms decreased when the dynamic soil properties (soil moisture, bulk density or total porosity) were used as secondary variables $(0.3-0.9 \mathrm{~km})$. The suitability of soil texture and organic carbon data to be used as secondary variables in cross-semivariograms for predicting spatial cross-correlations of SHC can be enhanced by their worldwide availability in soil geographic databases. The kriged maps allowed outlining two sub-areas with predominance of SHC >3.0 $\mathrm{m} \mathrm{day}{ }^{-1}$ in the northern part (latitude 52.01-52.06) and $<3.0 \mathrm{~m} \mathrm{day}^{-1}$ in the southern part of the commune. The comparison of the spatial maps indicates that there is positional similarity (agreement) between the sub-areas with the highest SHC values and the largest sand contents $(>74 \%)$. The spatial maps generated in this study can be helpful for the commune authorities 
and agronomy advisers for spatial planning of management practices aimed at reduction of SHC of permeable and low-productive soils.

\section{References}

1. Blanco-Canqui, H., Wienhold, B.J., Jin V.L., Schmer, M.R. \& Kibet, L.C. Long-term tillage impact on soil hydraulic properties. Soil Tillage Res 170, 38-42 (2017).

2. Zhao, C., Shao, M.A., Jia, X., Nasir, M., Zhang, C., Using pedotransfer functions to estimate soil hydraulic conductivity in the Loess Plateau of China. Catena 143, 1-6 (2016).

3. Keller, T., Sutter, J.A., Nissen, K. \& Rydberg, T. Using field measurement of saturated soil hydraulic conductivity to detect low-yielding zones in three Swedish fields. Soil Tillage Res 124, 68-77 (2012).

4. Bigelow, C.A., Bowman, D.C. \& Cassel, D.K. Physical properties of three sand size classes amended with inorganic materials or sphagnum peat moss for putting green rootzones. Crop Sci 44, 900-907 (2004).

5. Abel, S., Peters, A., Trinks, S., Schonsky, H., Facklam, M. \& Wessolek, G. Impact of biochar and hydrochar addition on water retention and water repellency of sandy soil. Geoderma 202-203, 183-191 (2013).

6. Li, Y., Gao, R., Yang, R., Wei, H., Li, Y., Xiao, H. \& Wu, J. Using a simple soil column method to evaluate soil phosphorus leaching risk. Clean-Soil, Air, Water 41, 1100-1107 (2013).

7. Fleige, H. \& Horn, R. Field experiments on the effect of soil compaction on soil properties, runoff, interflow and erosion. In: Horn, R., Van den Akker, J.J.H., Arvidsson, J. (Eds.), Subsoil, Compaction, Distribution, Processes and Consequences. Adv Geoecol vol. 32. Catena Verlag, Germany, pp. 258-268 (2000).

8. Jadczyszyn, J. \& Niedźwiecki, J. Relation of saturated hydraulic conductivity to soil losses. Pol J Environ Stud 14, 431-435 (2005).

9. Zhang, X., Wendroth, O., Matocha, C., Zhu, J. \& Reyes, J. Assessing field-scale variability of soil hydraulic conductivity at and near saturation. Catena 187, 104335, doi: 10.1016/j.catena.2019.104335 (2019).

10. Wösten, J.H.M., Veerman, G.J., de Groot, W.J.M. \& Stolte, J. Waterretentie - en doorlatendheidskarakteristieken van boven - en ondergronden in Nederland: de Staringreeks (Water retention and hydraulic conductivity characteristics of topsoils and 
subsoils in The Netherlands: the Staring series). Alterra rapport 153, Alterra, Wageningen, The Netherlands, 86 p. (2001).

11. Van den Akker, J.J.H. Evaluation of soil physical quality of Dutch subsoils in two databases with some threshold values. In: Horn, R., Fleige, H., Peth, S.,Peng, X. (Eds.), Soil Management for Sustainability. Advances in GeoEcology 38. Catena Verlag, Reiskirchen, Germany, pp. 490-497 (2006).

12. Reynolds, W.D., Bowman, B.T., Brunke, R.R., Drury, C.F. \& Tan, C.S. Comparison of tension infiltrometer, pressure infiltrometer, and soil core estimates. Soil Sci Soc Am J 64, 478-484 (2000).

13. Gliński, J. \& Lipiec, J. Soil Physical Conditions and Plant Roots1st Edition, CRC Press, 260 Pp, First Published 1990. Reissued 2018 by CRC Press Taylor \& Francis Group ISBN 13: 978-1-351-07670-8 (ebk) (2018).

14. van Genuchten, M.T. A closed-form equation for predicting the hydraulic conductivity of unsaturated soils. Soil Sci Soc Am J 44, 892-898 (1980).

15. Bevington, J., Piragnolo, D., Teatini, P., Vellidis, G. \& Morari, F. On the spatial variability of soil hydraulic properties in a Holocene coastal farmland. Geoderma, 262, 294-305 (2016).

16. Pagliai, M., Marsili, A., Servadio, P., Vignzzi, N. \& Pellegrini, S. Changes in some physical properties of a clay soil in Central Italy following the passage of rubber tracked and wheeled tractors of medium power. Soil Tillage Res 73, 119-129 (2003).

17. Lipiec, J. \& Hatano, R. Quantification of compaction effects on soil physical properties and crop growth. Geoderma 116, 107-136 (2003).

18. Zhao, Y., Peth, S., Horn, R., Krümmelbein, J., Ketzer, B., Gao, Y., Doerner, J., Bernhofer, C. \& Peng, X. Modeling grazing effects on coupled water and heat fluxes in Inner Mongolia grassland. Soil Tillage Res 109, 75-86 (2010).

19. Strudley, M.W., Green, T.R. \& Ascough Ii, J.C. Tillage effects on soil hydraulic properties in space and time: state of the science. Soil Tillage Res 99, 4-48 (2008).

20. Godoy, V.A., Zuquette, L.V. \& Gómez-Hernández, J.J. Spatial variability of hydraulic conductivity and solute transport parameters and their spatial correlations to soil properties. Geoderma 339, 59-69 (2019).

21. Kim, H., Anderson, S.H., Motavalli, P.P. \& Gantzer, C.J. Compaction effects on soil macropore geometry and related parameters for an arable field. Geoderma 160, 244-251 (2010). 
22. Centeno, L.N., Hu, W., Timm, L.C. et al. Dominant Control of Macroporosity on Saturated Soil Hydraulic Conductivity at Multiple Scales and Locations Revealed by Wavelet Analyses. J Soil Sci Plant Nutr 20, 1686-1702, https://doi.org/10.1007/s42729020-00239-5 (2020).

23. Azadmard, B., Mosaddeghi, M.R., Ayoubi, S., Chavoshi, S. \& Raoof, M. Spatial variability of near-saturated soil hydraulic properties in Moghan plain, North-Western Iran. Arab J Geosci 11, 452, https://doi.org/10.1007/s12517-018-3788-8 (2018).

24. Adamchuk, V.I. \& Viscarra Rossel, R.A. Precision agriculture: Proximal soil sensing. In J.Gliński, J. Horabik, and J. Lipiec (eds.) Encyclopedia of Agrophysics, pp. 650-656. Springer, New York (2011).

25. Bogunovic, I., Mesic, M., Zgorelec, Z., Jurisic, A. \& Bilandzija, D. Spatial variation of soil nutrients on sandy-loam soil. Soil Tillage Res 144, 174-183, doi:10.1016/j.still.2014.07.020 (2014).

26. Hedley, C.B. \& Yule, I.J. Soil water status mapping and two variable-rate irrigation scenarios. J Prec Agric 10, 1385-2256 (2009).

27. Villagra-Mendoza, K. \& Horn, R. Effect of biochar on the unsaturated hydraulic conductivity of two amended soils Int Agrophys 32, 373-378 (2018).

28. Miller, J.J., Sweetland, N.J., Larnry, F.J. \& Volkmar, K.M. Unsaturated hydraulic conductivity of conventional and conservation tillage soil in southern Alberta. Can J Soil Sci 78, 643-648 (1998).

29. Goovaerts, P. Geostatistics for natural resources evaluation. 483 (1997).

30. Webster, R. Soil science and geostatistics. In: Krasilnikov, P., Carré, F., Montanarella,L. (Eds.), Soil Geography and Geostatistics. Concepts and Applications. JRC Scientific and Technical Reports. Office for Official Publications of the European Communities, Luxembourg, (Chapter 1), pp. 1-11 (2008).

31. Jabro, J. D., Stevens, W. B., Iversen, W. M. \& Evans, R. G. Tillage Depth Effects on Soil Physical Properties, Sugar beet Yield, and Sugar beet Quality. Commun Soil Sci Plant Anal 41, 7, 908-916, doi:10.1080/00103621003594677 (2010).

32. Moradi, F., Moosavi, A.A. \& Moghaddam, B.K. Spatial variability of water retention parameters and saturated hydraulic conductivity in a calcareous Inceptisols (Khuzestan province of Iran) under sugarcane cropping. Arch Agron Soil Sci 62(12), 1686-1699, https://doi.org/10.1080/03650340.2016.1164308 (2016). 
33. Mertens, J., Jacques, D., Vanderborght, J. \& Feyen, J. Characterisation of the field saturated hydraulic conductivity on a hillslope: in situ single ring pressure infiltrometer measurements. J Hydrol 263, 217-229 (2002).

34. Deurer, M. \& Duijnisveld, W. Spatial analysis of water characteristic functions in a sandy podzol under pine forest. Water Resour Res 36(10), 2925-2935 (2000).

35. Gumiere, S.J., Lafond, J.A., Hallema, D.W., Périard, Y., Caron, J. \& Gallichand, J. Mapping soil hydraulic conductivity and matric potential for water management of cranberry: characterisation and spatial interpolation methods. Biosyst Eng 128, 29-40 (2014).

36. Li, Y., Chen, D., White, R.E., Zhu, A. \& Zhang, J. Estimating soil hydraulic properties of Fengqiu County soils in the North China Plain using pedo-transfer functions. Geoderma 138, 261-271 (2007).

37. Wang, Y., Shao, M.A. \& Liu, Z. Pedotransfer functions for predicting soil hydraulic properties of the Chinese Loess Plateau. Soil Sci 177, 424-432 (2012).

38. IUSS Working Group W.R.B. World Reference base for soil resources 2014, update 2015. International soil classification system for naming soils and creating legends for soil maps. World Soil Resources Reports No. 106. FAO, Rome (2015).

39. Blake, G.R. \& Hartge, K.H. Bulk density. In: Klute, A. (Ed.), Methods of Soil Analysis. 1. Physical and Mineralogical Methods. ASA-SSSA Inc., Madison, Wisconsin, USA, pp. 363-375 (1986b).

40. Klute, A. \& Dirksen, C. Hydraulic conductivity and diffusivity: laboratory methods. In: Klute, A. (Ed.), Methods of Soil Analysis. Part 1. Physical and Mineralogical Methods. SSA Book Series Vol. 5 (1986b).

41. Ostrowska, S., Gawliński, Z. \& Szczubiałka, Z. Procedures for Soil and Plant Analysis. Institute of Environmental Protection, Warsaw, Poland (in Polish) (1991).

42. Blake, G.R. \& Hartge, K.H. Particle density. In: Klute, A. (Ed.), Methods of Soil Analysis. 1. Physical and Mineralogical Methods. ASA-SSSA Inc., Madison, Wisconsin, USA, pp. 377-382 (1986a).

43. Danielson, R.E. \& Sutherland, P.L. Porosity. In: Klute, A. (Ed.), Methods of Soil Analysis. 1. Physical and Mineralogical Methods. ASA-SSSA Inc., Madison, Wisconsin, USA, pp. 443-460 (1986).

44. Dahiya, I.S., Ritcher, J. \& Mark, P.S. Soil spatial variability: review. Int J Trop Agric 11, 1-102 (1984). 
45. Robertson, G.P. GS+: Geostatistics for the Environmental Sciences; Gamma Design Software: Plainwell, Michigan USA (2008).

46. Perfect, E., Groenevelt, P.H., Kay, B.D. \& Grant, C.D. Spatial variability of soil penetrometer measurements at the mesoscopic scale. Soil Tillage Res 16, 257-271 (1990).

47. Brocca, L., Hasenauer, S., Lacava, T., Melone, F., Moramarco, T., Wagner, W., Dorigo, W., Matgen, P., Martines-Fernandez, J., Llorens, P., Latron, J., Martin, C. \& Bitelli, M. Soil moisture estimation through ASCAT and AMSR-E sensors: an intercomparison and validation study across Europe. Remote Sens Environ 115, 3390-3408, doi:10.1016/j.rse.2011.08.003 (2011).

48. Cambardella, C.A., Moorman, T.B., Parkin, T.B., Karlen, D.L., Novak, J.M., Turco, R.F. \& Konopka, A.E. Field-scale variability of soil properties in Central Iowa soils. Soil Sci Soc Am J 58, 1501-1511 (1994).

49. Rzymowska, Z. \& Skrajna, T. Associations and communities of the cereal crops of the Łuków Plain. Part. I. Light soil associations. Acta Agrobot 64(4), 243-250, http://dx.doi.org/10.5586/aa.2011.066 (2011).

50. Usowicz, B. \& Lipiec, J. Spatial variability of soil properties and cereal yield in a cultivated field on sandy soil. Soil Tillage Res 174, 241-250 (2017).

51. Paz-Ferreiro, J., Vázquez, E.V. \& Miranda, J.G.V. Assessing soil particle-size distribution on experimental plots with similar texture under different management systems using multifractal parameters. Geoderma 160(1), 47-56 (2010).

52. Vieira, S.R. \& Gonzalez, A.P. Analysis of the spatial variability of crop yield and soil properties in small agricultural plots. Bragantia Campina. 62, pp. 127-138 (2003).

53. Batjes, N. H., Ribeiro, E., \& van Oostrum, A. Standardised soil profile data to support global mapping and modelling (WoSIS snapshot 2019), Earth Syst Sci Data 12, 299-320, https://doi.org/10.5194/essd-12-299-2020 (2020).

54. Stryjewski, F. Drenowanie. PWN, Warszawa. (in Polish) (1987).

55. Chartiera, M.P., Rostagno, C.M. \& Pazos, G.E. Effects of soil degradation on infiltration rates in grazed semiarid rangelands of north-eastern Patagonia, Argentina. J Arid Environ $275,656-661(2011)$.

56. Lim, T.J., Spokas, K.A., Feyereisen, G. \& Novak, J.M. Predicting the impact of biochar additions on soil hydraulic properties. Chemosphere 142, 136-144 (2016).

57. Lipiec J. \& Usowicz B. Spatial relationships among cereal yields and selected soil physical and chemical properties. Sci Total Environ 633, 1579-1590 (2018). 
58. Ajayi, A.E. \& Horn, R. Comparing the potentials of clay and biochar in improving water retention and mechanical resilience of sandy soil. Int Agrophys 30, 391-399 (2016).

59. Becher, M. Properties of organic matter of soil fertilised with spent mushroom (Agaricus L.) substrate. Acta Agroph 20(2), 241-252 (2013).

60. Frąc, M., Pertile, G., Panek, J., Gryta, A., Oszust, K., Lipiec, J. \& Usowicz, B. Ecological responses of soil fungal community microbiome to spent mushroom substrate and chicken manure amendment. Sustainability Science (under review) (2021).

61. Abdollahi, L., Munkholm, L.J. \& Garbout, A. Tillage System and Cover Crop Effects on Soil Quality: II. Pore Characteristics. Soil Sci Soc Am J 78, 271 (2014).

62. Adetunji, A.T., Ncube, B., Mulidzi, R. \& Lewu, F.B. Management impact and benefit of cover crops on soil quality: A review. Soil Tillage Res 204, 104717 (2020).

63. Tamm, I., Tamm, Ü., Ingver, A., Koppel, R., Tupits, I., Bender, A., Tamm, S., Narits, L. \& Koppel, M. Different leguminous pre-crops increased yield of succeeding cereals in two consecutive years. Acta Agr Scand, Section B - Soil and Plant Science 66, 593-601, https://doi.org/10.1080/09064710.2016.1205125 (2016).

64. Baumhardt, R.L., Johnson, G.L. \& Schwartz, R.C., Residue and long term tillage and crop rotation effects on simulated rain infiltration and sediment transport. Soil Sci Soc Am J 76, 1370-1378, https://doi.org/10.2136/1556 (2012).

65. Blanco-Canqui, H., Shaver, T.M., Lindquist, J.L., Shapiro, C.A., Elmore, R.W., Francis, C.A. \& Hergert, G.W. Cover crops and ecosystem services: insights from studies in temperate soils. Agronomy Journal, 107(6), 2449, doi:10.2134/agronj15.0086 (2015).

66. Wysokiński, A. \& Kuziemska, B. The sources of nitrogen for yellow lupine and spring triticale in their intercropping. Plant Soil Environ 65, 145-151 (2019).

67. Hu, T., Taghizadeh-Toosi, A., Olesen, J.E., Jensen, M.L., Sørensen, P. \& Christensen, B.T. Converting temperate long-term arable land into semi-natural grassland: decadalscale changes in topsoil C, N, 13C and 15N contents. Eur J Soil Sci 70, 350-360, https://doi.org/10.1111/ejss.12738 (2019).

68. Alaoui, A., Lipiec, J. \& Gerke, H.H. A review of the changes in the soil pore system due to soil deformation: a hydrodynamic perspective. Soil Tillage Res 115-116, 1-15 (2011).

69. Håkansson, I. \& Lipiec, J. A review of the usefulness of relative bulk density values in studies of soil structure and compaction. Soil Tillage Res 53, 71-85 (2000).

70. Thomasson, A.J. Soils and Field Drainage. Soil Survey Technical Monograph No.7. Soil Survey of England and Wales. (Lawes Agricultural Trust: Harpenden) (1975). 
71. Huber, S., Prokop, G., Arrouays, D., Banko, G., Bispo, A., Jones, R.J.A., Kibblewhite, M.G., Lexer, W., Möller, A., Rickson, R.J., Shishkov, T., Stephens, M., Toth, G. Van den Akker, J.J.H., Varallyay, G., Verheijen, F.G.A. \& Jones, A.R. (eds) Environmental Assessment of Soil for Monitoring: Volume I Indicators \& Criteria. EUR 23490 EN/1, Office for the Official Publications of the European Communities, Luxembourg, 339pp. (2008).

Acknowledgements. The research was conducted (partially funded) as part of the project "Water in soil - satellite monitoring and improving the retention using biochar" no. BIOSTRATEG3/345940/7/NCBR/2017, which was financed by the Polish National Centre for Research and Development in the framework of the "Environment, agriculture and forestry" - BIOSTRATEG strategic R\&D programme.

\section{Contributions}

B.U. performed the experiments and measurements and carried out data analysis, B.U., J.L. wrote the paper.

\section{Additional Information}

Competing Interests: The authors declare no competing interests. 


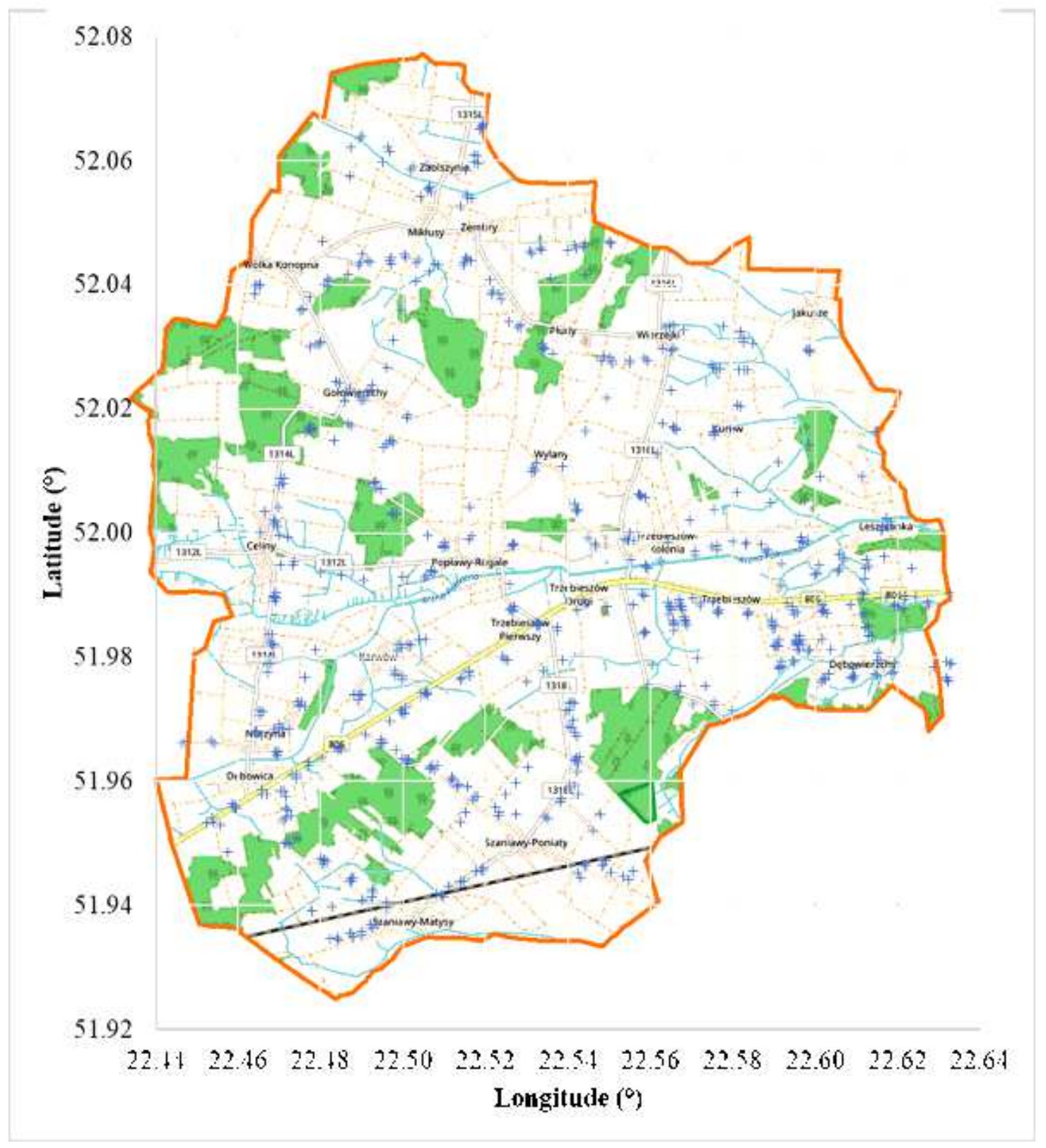

\section{Figure 1}

Location of sampling points in Trzebieszów commune. Background maps from https://upload.wikimedia.org/wikipedia/commons/d/d4/Trzebiesz\%C3\%B3w_\%28gmina\%29_location_map.png Note: The designations employed and the presentation of the material on this map do not imply the expression of any opinion whatsoever on the part of Research Square concerning the legal status of any country, territory, city or area or of its authorities, or concerning the delimitation of its frontiers or boundaries. This map has been provided by the authors. 


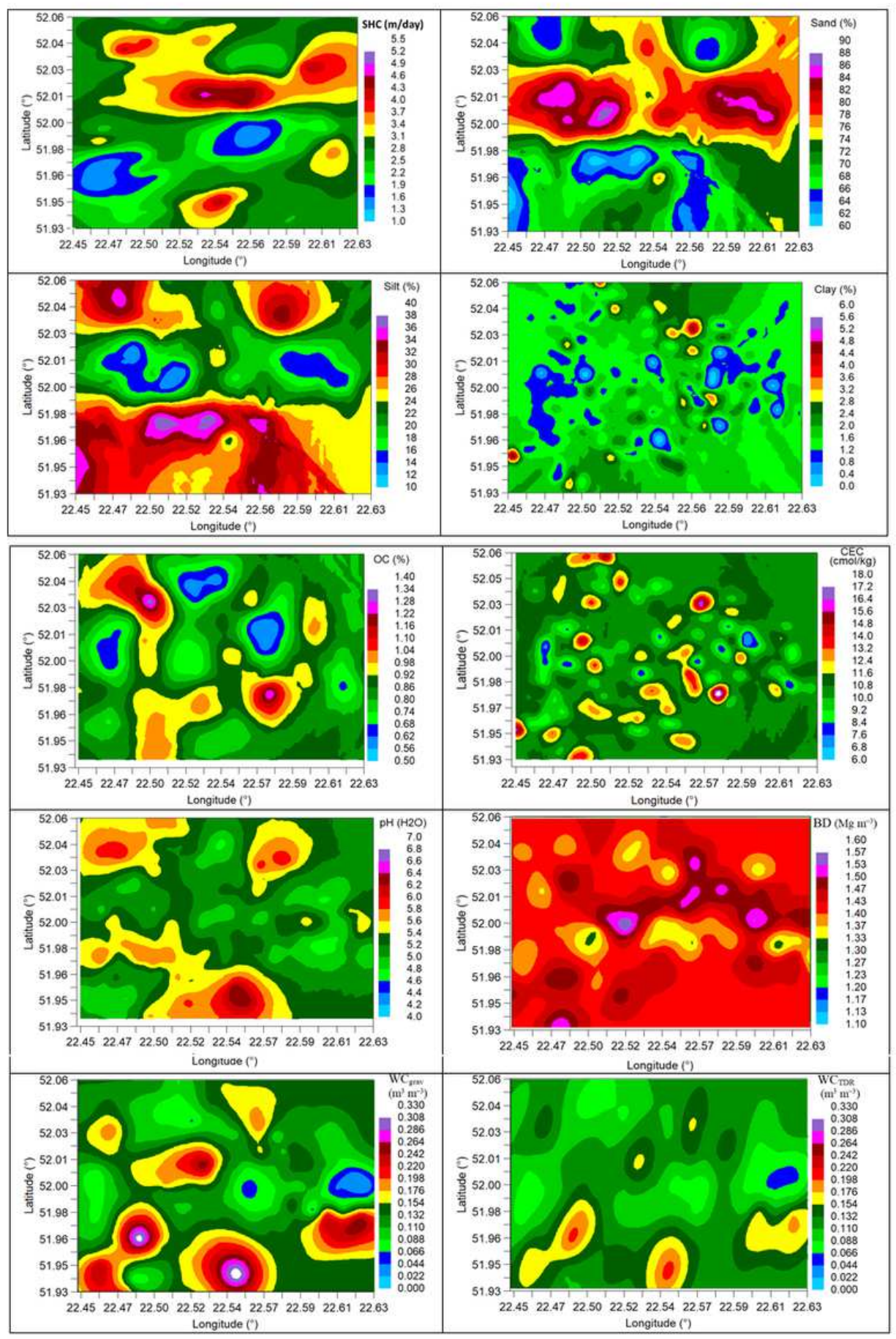

Figure 2

Maps of saturated hydraulic conductivity (SHC), sand, silt, and clay contents, soil organic carbon (OC), cation exchange capacity (CEC), pH, bulk density (BD), gravimetric water content (WCgrav) and TDR water content (WCTDR) in Trzebieszów commune 